\title{
Corporate Governance, Risk-taking and Efficiency of Islamic Banks: Comparative Study Between Pakistan and Malaysia
}

\author{
Qaiser Abbas $\otimes^{1}$ \\ Department of Commerce Bahauddin Zakariya University, Multan, Pakistan ${ }^{1}$
}

\begin{abstract}
Purpose: This study aims to compare the governance, risk-taking, and efficiency of pure Islamic Banks between Pakistan and Malaysia.

Design: Total 9 years of data from 2009 to 2017 used for analysis. Data Envelopment Analysis (DEA) has been used for the measurement of Islamic bank's efficiency. Efficiency has been measured by (Technical Efficiency, Pure Technical Efficiency, and Scale Efficiency). Z-score has been used to measure risk-taking. Results: This comparative study shows that Shariah Supervisory Board has a significant impact only on Malaysian Islamic Banks with technical, pure technical, and scale efficiency. At the same time, board independence has a meaningful relationship with the efficiency of IBs of both countries. Board meetings significantly impact Pakistani Banks' pure technical efficiency while it substantially affects Malaysian banks' technical efficiency. Results also show that risk-taking has a significant negative impact on the efficiency of both countries.

Implications: Pakistani Islamic banks should focus more on Shariah Supervisory Boards to develop the Islamic Banking system in Pakistan because it significantly impacts the Efficiency of Malaysian IBs.
\end{abstract}

$凶$ Corresponding author: qaiserabbas1515@gmail.com

\author{
ARTICLE INFO \\ Received: December 23, 2020 \\ Revised: February 9 \& 14, 2021 \\ Accepted: February 14, 2021 \\ Published: February 14, 2021
}

\section{Keywords:}

Efficiency of Islamic banks

Risk-taking

Governance of Islamic banks

(cc) BY (C) 2021 The Author(s)

\section{Introduction}

Banking efficiency is the combination of all these strategies. Banks are aware of their all resources and select such a variety that offers maximum output with minimum input. Banks that adopt such type of combination for their resources become more efficient than others. It helps to become more efficient for all kinds of competition in the advanced technological era. The measurement of banks' efficiency includes calculating their efficiency scores under efficiency limit through non-parametric or parametric tactics. Data Envelopment Analysis (DEA) is the most common method which is used to measure banking efficiency. DEA is based on two basic models. The first one is the CCR model, which has been established by (Chames, Cooper, 
\& Rhodes, 1978). CCR model is based on the assumption of CRS consistency (constant return to Scale) for apiece decision-making unit. The second model is BCC, established by (Banker, Charnes, \& Cooper, 1984).

BCC model is based on the assumption of the inconsistency of return to Scale called variance return to scale (VRS) for each decision-making unit. Efficiency is measure through the difference between the situation of the company and the efficiency limit. The difference is expressed through scores of efficiencies, which lies among 0 and 1 . If this spread is equal to unity, there is total efficiency of a given unit. Thus, as these scores are away from 1, it leads to a superficial efficiency level. When this condition occurs, then it is compulsory to seek and explain this case of inefficiency. A good corporate governance structure helps to minimize corporate risk, enhances the corporate value, and leads towards the fairness of accounts, hence operational efficiency and bank productivity increase (Fu, Lin, \& Molyneux, 2014).

In literature, many studies indicate that a good corporate governance structure enhances efficiency in banks' case (Adams \& Mehran, 2012; De Andres \& Vallelado, 2008; Musa, 2020). All these studies indicate a positive relationship between governance and bank efficiency by supporting an argument that through good governance structure, banks become able to reduce the cost of their capital and better utilize their resources, which ultimately enhance efficiency. Agency theory supports this argument in which managers work for the shareholder's best interests (Jensen \& Meckling, 1976). The governance structure enforces its managers to decrease asymmetry into the information, which leads to the agency problem. Hence it makes firms to be more productive and efficient.

Corporate governance has significantly enhanced the efficiency of Islamic banks. It has become stronger by developing Islamic Financial Institutions (IFIs) (Saeed \& Saeed, 2018). Now a day, Malaysia is playing a crucial role in the development of Islamic Financial Institutions. The current Govt. of Pakistan is also leading Pakistan towards a model of Riyasat-E-Madina, which will be based on Shariah Principles. In this case, Pakistani society will move towards Islamic Financial System. As Malaysia has an excellent Islamic Banking System, so in this study, we will compare the governance, risk-taking, and efficiency of Islamic Banks of Pakistan and Malaysia. This comparison will provide new insight to Pakistani Islamic banks' policymakers that how can IBs become more developed in Pakistan like Malaysia. We will highlight those elements that help the Islamic banking sector become more efficient in Pakistan like Malaysia.

\section{Literature Review}

Many studies have been conducted to explore banking efficiency determinants (Aly, Grabowski, Pasurka, \& Rangan, 1990; Pasiouras, 2008; Spong, Sullivan, \& DeYoung, 1995). Hassan and Hussein (2003) studied Islamic banking efficiency in Sudan through the "Data Envelopment Analysis" (DEA) technique. According to Yudistira (2004), Islamic banks can quickly achieve perfect efficiency scores. This study also explored that during the Asian crisis of 1999s, IBs efficiency declined. This study also addressed that the decline in efficiency scores was basically due to pure technical inefficiency (PTE) than the efficiency scale.

Middle Eastern Islamic banks were found to be more efficient than others. While on the other hand, Sufian and Noor (2009) indicate that Islamic banks of the MENA region have high technical efficiencies compared to other Islamic banks of Asia. Islamic banks put a higher score on technical efficiency (Abdul Rahman \& Rosman, 2013). The study results also reveal that Islamic banks that are operational in the Southeast Asia region have a high-efficiency level compared to those Islamic banks that operate in the MENA region. In this study, they have also compared MENA region IBs with Gulf countries. From this perspective, results reveal that IBs which operate in Gulf countries are also more efficient than the MENA region. Authors conclude that the country's economic conditions are considered a key determinant of Islamic bank's efficiency.

Hassine and Limani (2014) studied Islamic banks' efficiency in the MENA region by using five years of data from 2005 to 2009. They used the DEA method for the measurement of efficiency. Authors found that technical efficiency was the critical determinant of Islamic banks' inefficiency compared to scale efficiency. Scale 
efficiency had high scores as compared to technical efficiency. This study also compared Islamic banks' size and found that Islamic banks with small size had more efficiency than large-sized banks. (Kamarudin, Sufian, Loong, \& Anwar, 2017) studied a comparative study between foreign and domestic Islamic banks in Brunei, Malaysia, and Indonesia using nine years of data from 2006 to 2014. The study results reveal that domestic banks have a higher level of technical, pure technical, and scale efficiencies in targeted countries of the study. Results also indicate that Islamic banks are inefficient in controlling costs.

Srairi, Kouki, and Harrathi (2012) studied a sample of 25 pure Islamic banks of Gulf countries by using seven years of data from 2003 to 2009. In this study, they examined the association between the efficiency of Islamic banks and their share performance. The study results revealed that a change in pure technical efficiency and technical efficiency has a positive relationship with equity return. Results also show that scale efficiency does not influence return on equity. Simultaneously, the technical efficiency of Islamic banks is mainly based on the wrong Scale of their operations. Bahrini (2017) studied the determinants of Islamic banks' efficiency of MENA region Islamic banks using six years of data from 2007 to 2012. The study results show that pure technical inefficiency was a key determinant of technical inefficiency compared to scale inefficiency of all Islamic banks of the MENA region. After the study's findings, the author recommends that managers focus more on their management practices and not increase board size.

Bader, Mohamad, Ariff, and Shah (2008) found no difference in the performance of Islamic vs. conventional banks. Both types of banks are highly efficient in terms of resource utilization and generate efficient revenues. While Johnes, Izzeldin, and Pappas (2009) studied a comparative analysis of Conventional and Islamic banks' efficiency of the GCC region by using six years of data from 2004 to 2007. Results of the study revealed that conventional banks were more efficient than Islamic banks of the GCC region.

According to Ahmad, Noor, and Sufian (2010), Islamic banks were found more efficient than conventional banks in their management planning. This study also indicates that banks perform well, which operate in countries with a high-income level compared to low-income countries. Haron, Abu Bakar, and Tahir (2011) found out that Islamic banks' size was considered a key determinant of efficiency. The larger banks were found to be more efficient. Olson and Zoubi (2011) conducted a comparative study about banks' efficiency in the MENA region and European region. They found out that banks of the MENA region were less efficient than banks of the European region. The author also concluded that banks had the same efficiency level in developing and developed countries. Finding also indicated that all banks of the MENA region were below the optimal size.

Gishkori and Ullah (2013) conducted a comparative study between conventional and Islamic banks' efficiency in Pakistan by using the CRS model. Results of the study indicated that Islamic banks were less efficient than traditional banks of Pakistan. Results also showed that the scale efficiency of both Islamic and Conventional banks was the same. They also studied the determinants of technical efficiency and found that ownership, size of the bank, and profitability were the determinants of efficiency. (Said, 2012) learned the efficiency of Islamic banks during the 2008 crisis. The study results indicated that from 2006 to 2008, Islamic banks' efficiency increased, but it declined during 2009. During the 2008 crisis, Islamic banks of the Middle East had a higher level of efficiency.

Said (2013) conducted a study to measure the technical efficiency of Islamic banks of the MENA region and some other Islamic banks during the economic crisis of 2008. Results of the study revealed that Islamic banks other than the MENA region were found as technically inefficient. Furthermore, results also showed that putrefaction of "Technical efficiency" into both pure technical and scale efficiency indicated that Islamic banks other than the MENA region had their resource allocation problem. (Rosman, Abd Wahab, \& Zainol, 2014) Studied efficiency of Islamic banks by using 79 Islamic banks of the Middle East and Asia by using four years of data from 2007-2010 to examine the economic crisis of 2008. The study results revealed that during the economic crisis of 2008, Islamic banks were found to be managed well in all activities and operations. While 
due to the economic crisis, most Islamic banks had an inefficient Scale due to declines in returns. Results also revealed that capitalization and profitability were critical determinants of the Islamic bank's efficiency during the economic crisis. According to Johnes, Izzeldin, and Pappas (2014), Islamic banks and conventional banks had no difference in efficiency immediately after the economic crisis. But, by performing a "met-frontier analysis," they found that traditional banks had more efficiency than Islamic banks.

Our study will examine the efficiency of Islamic banks by comparing Pakistan and Malaysian Islamic banks through determinants of governance and risk-taking. Malaysia has many Islamic banks, and they have more proportion of the Islamic banking industry. So, we will make its governance, risk-taking, and efficiency comparison with Pakistani Islamic banks. Now a day, in Pakistan, Islamic banking is rapidly growing up. So, we will examine whether the management practices in the Islamic banks of Malaysia and Pakistan.

Many studies in the literature have explored the association between management and a firm's performance. There are mixed results of these studies. Some have a positive relationship, and some show a negative relation between governance and firm performance. Bhagat and Black (2001) studied corporate governance's significant connection with performance. Rashid, De Zoysa, Lodh, and Rudkin (2010) indicated that the director's independence has no impact on firm performance. Independent directorship can enhance transparency but does not affect the business firms' economic value. (Alabdullah, Yahya, \& Ramayah, 2014; Brown \& Caylor, 2006; Yusoff \& Alhaji, 2012) all indicate that corporate governance has a constructive influence on firm performance.

Mitton (2002) asserts that small-level shareholders' rights and quality and transparency in financial reports are critical to corporate governance. They also indicate that good corporate governance can manage well during economic distress. (Klapper and Love (2004) found that good financial performance is positively correlated with good corporate governance. Bhagat and Bolton (2008) investigated that board extent and CEO duality of duties have an optimistic consequence on firm performance. A few studies like Drakos and Bekiris (2010) and Basyith (2016) found an adverse association between corporate governance and firm performance.

Mezzi (2018) studied the relationship between governance and efficiency of Islamic banks. Results showed that as governance size reduced, banks became more efficient. Mohd Abbas, Abdul Rahman, and Mahenthrian (2009) studied ownership structure and performance of Islamic Financial Institutions of Malaysia and found out that government, families, and institutional ownership had a significant impact on the performance of IFIs. As part of governance, ownership structure did not affect Islamic banks' performance (Zouari \& Taktak, 2014). The Shariah supervisory board's size had a positive impact on Islamic banks' performance in their supervisory role (Mollah \& Zaman, 2015). At the same time, CEO duality harms the implementation of Islamic banks. Khan and Shah (2015) conducted a comparative study between Islamic and conventional banks of Pakistan. Results showed that Islamic banks had better technical efficiency as compared to traditional banks. The pure technical efficiency of Islamic banks was also better than conventional banks of Pakistan. Abbas, Yussof, and Anjum (2020) found that the Shariah supervisory board ( Shariah Board reputation, Expertise, Cross-membership, Change in composition, and Qualifications of Shariah Supervisory board) have a significant impact on the performance of Islamic banks. Sufian (2007) conducted a study to examine efficiency of Malaysian Islamic banks by using five years of data from 2001-2005. Results showed that scale inefficiency was stood over pure technical inefficiency. Results also showed that domestic Islamic banks were more efficient than foreign.

\section{Methodology}

\section{Data Envelopment Analysis as Measure of Efficiency}

Farrell developed DEA (Data Envelopment Analysis) method in 1957. Still, the DEA model was projected by Charl, which is known as CCR (Charnes, cooper, and Rhoades) model with CRS (constant return 
to Scale). Afterward, Banker et al. (1984) extended it and allowed the Variables return scale (VRS). VRS is based on the assumption that technical efficiency is disintegrated into PTE (pure technical efficiency) used for management efficiency and into SE (scale efficiency), which is used as an optimal size indicator DEA method helps to identify all these sources of inefficiency, which are not shown in financial rations.

VRS explores all these sources, which leads toward inefficiency due to optimal size or management structure. VRS is widely used because it is better for assessment as banks operate in an imperfectly competitive environment. In this study, we will use both VRS and CRA assumptions in which under CRS assumption, it is assumed that banks are operated at optimal Scale. Under the VRS assumption, it is assumed that regulatory variations and technical progress are due to banks' different sizes. Technical efficiency indicates the ability of banks in which banks use minimum inputs and generate maximum output. While pure technical efficiency means banks' ability to minimize wastage of resources and scale efficiency increases as banks approach their optimal sizes.

\section{Sample Size}

This research study will compare governance, risk-taking, and efficiency among Islamic banks of Pakistan and Malaysia. We have used nine years of hand-collected data from the period of 2009 to 2017. We have selected a total of 8 pure Islamic banks. We have Selected 5 Islamic banks from Malaysia and 3 Islamic banks from Pakistan. In this study, to measuring efficiency of Islamic banks, we have used three inputs (deposit, operating fixed cost, and HR cost) and two outputs (investment and financing).

\section{Research Design}

The impact of governance and risk-taking on the efficiency of Islamic banks of Malaysia and Pakistan has been assessed using the following equation.

$$
\begin{aligned}
& E F F_{I}=\beta_{0}+\beta_{1} S S B-S i z e+\beta_{2} B_{S I Z E_{I}}+\beta_{3} B-I N D_{I}+\beta_{4} B-M E T_{I}+\beta_{5} C E O D_{I}+\beta_{6} C G-F M_{I}+\beta_{7} F-S I Z E_{I}+ \\
& \beta_{8} \text { PRFT }_{I}+\beta_{9} \text { RISK-T } T_{I}+\mu_{t}
\end{aligned}
$$

\section{Measurement of Variables}

Measurement of the above-discussed variables has been given below:

\begin{tabular}{ll}
\hline Variable & Measurement of Variables \\
\hline SSB-SIZE & Total number of Shariah supervisory board \\
BSIZE & Total number of Board of Directors \\
B-IND & $\%$ of Independent directors inboard \\
B-MET & Number of total annual meetings of the board \\
CEOD & Dummy 1 if there is CEO duality; otherwise 0. \\
CG-FM & $\%$ of Females on board \\
F-SIZE & Log of total assets \\
PRFT & Return on Assets \\
RISK-T & Z-Score \\
Efficiency & Inputs $=$ Deposits + Operating Fixed Cost + HR cost \\
Out puts = Investments + Financing \\
\hline
\end{tabular}

\section{Results and Discussion}


Table 1 - Descriptive Statistics of Pakistani IBs

\begin{tabular}{|c|c|c|c|c|c|c|c|c|c|c|c|c|}
\hline Variable & TE & PTE & SE & SSB-SIZE & BSIZE & B-IND & B-MET & CEOD & CG-FM & F-SIZE & PRFT & RISK_T \\
\hline Mean & 0.282 & 0.604 & 0.527 & 0.618 & 0.918 & 0.347 & 0.538 & 0.667 & 0.292 & 7.927 & 0.008 & 0.931 \\
\hline Median & 0.369 & 0.483 & 0.556 & 0.602 & 0.903 & 0.286 & 0.699 & 1.000 & 0.000 & 7.906 & 0.010 & 1.025 \\
\hline Maximum & 0.583 & 0.914 & 0.914 & 0.778 & 1.114 & 0.857 & 0.903 & 1.000 & 1.200 & 8.972 & 0.017 & 1.580 \\
\hline Minimum & 0.012 & 0.413 & 0.015 & 0.477 & 0.699 & 0.000 & 0.000 & 0.000 & 0.000 & 7.119 & -0.014 & 0.276 \\
\hline Std. Dev. & 0.164 & 0.195 & 0.319 & 0.130 & 0.121 & 0.279 & 0.338 & 0.480 & 0.507 & 0.565 & 0.006 & 0.432 \\
\hline Skewness & 0.131 & 0.647 & -0.047 & 0.169 & 0.031 & 0.331 & -0.833 & 0.707 & 1.137 & 0.218 & -1.613 & -0.026 \\
\hline Kurtosis & 2.180 & 1.737 & 1.454 & 1.396 & 1.631 & 2.116 & 2.058 & 1.500 & 2.333 & 1.816 & 6.194 & 1.672 \\
\hline
\end{tabular}

Above table 2 below shows the descriptive statistics of the Islamic banks of Pakistan. Descriptive Statistics of the study shows that the Islamic banks of Pakistan have 28\% technical efficiency. Simultaneously, Pakistan's Islamic banks have a higher level of pure technical efficiency, which is about $60.4 \%$. The mean value of scale efficiency is $52.7 \%$, which means banks have $52.7 \%$ scale efficiency.

Table 2 - Correlation Analysis of Pakistani IBs

\begin{tabular}{llllllllll}
\hline Probability & SSB-SIZE & BSIZE & B-IND & B-MET & CEOD & CG-FM & F-SIZE & PRFT & RISK_T \\
\hline SSB_SIZE & 1.00 & & & & & & & & \\
BSIZE & -0.05 & 1.00 & & & & & & \\
B-IND & $-0.08^{* *}$ & $0.01^{* *}$ & 1.00 & & & & & \\
B-MET & $-0.03^{* *}$ & $0.02^{* *}$ & $0.06^{* *}$ & 1.00 & & & & \\
CEOD & $0.03^{* *}$ & 0.01 & -0.03 & $-0.08^{* *}$ & 1.00 & & & \\
CG-FM & $0.04^{* *}$ & $-0.04^{*}$ & $-0.10^{*}$ & $-0.15^{* *}$ & $0.09^{*}$ & 1.00 & & & \\
F-SIZE & $-0.05^{* *}$ & $0.03^{* *}$ & 0.04 & $0.09^{* *}$ & -0.08 & $-0.17^{* *}$ & 1.00 & & \\
PRFT & $0.05^{*}$ & 0.00 & 0.04 & $-0.09^{*}$ & $0.02^{* *}$ & $0.01^{*}$ & -0.01 & 1.00 & 1.00 \\
RISK_T & 0.01 & 0.01 & -0.02 & $-0.07^{* *}$ & $0.11^{* *}$ & $0.08^{*}$ & -0.02 & $0.03^{*}$ & 1.02 \\
\hline
\end{tabular}

Table 2 shows the correlation matrices of all independent variables. SSB size has a significant negative relationship with board size, board independence, board meetings, CEO duality of duties, females inboard, and firm size. At the same time, SSB size has a positive correlation only with profitability. Board size has a significant positive correlation with board independence, board meetings, and its size. At the same time, board size has a significant negative correlation with females on the corporate board. Board independence has a significant negative correlation with only females on board.

At the same time, board independence has a significant positive association with only board meetings. Board meetings have a significant negative correlation with CEO duality, females on board, profitability, and risk-taking. Board meetings have only a positive significant correlation with firm size. COE duality has a significant positive correlation with females in the board, profitability, and risk-taking while negatively correlated with only fit size. Females onboard show a significant positive correlation with profitability and risktaking. At the same time, it has a significant negative correlation with firm size. Profitably has a significant positive correlation with risk-taking.

Table 3 - Results of Pakistani IBs

\begin{tabular}{llll}
\hline & TE & PTE & SE \\
\hline SSB-SIZE & $-0.0763(0.8592)$ & $0.7701(0.1188)$ & $-1.2086^{* * *}(0.0039)$ \\
BSIZE & $-1.0926(0.1178)$ & $-0.2755(0.7121)$ & $-0.3787(0.5129)$ \\
B-IND & $0.3219^{* * *}(0.0017)$ & $0.0348^{* * *}(0.03)$ & $0.2381^{* *}(0.0565)$ \\
B-MET & $-0.4579(0.1289)$ & $0.8852^{* * *}(0.0126)$ & $-0.5828^{* * *}(0.0294)$ \\
CEOD & $0.2024(0.2728)$ & $-0.2686(0.1919)$ & $0.1764(0.2641)$ \\
CG-FM & $0.6995^{* * *}(0.0142)$ & $0.5395^{* *}(0.0739)$ & $0.4696^{* *}(0.0466)$ \\
F-SIZE & $0.1558(0.1056)$ & $0.0333(0.7451)$ & $0.2213^{* * *}(0.0113)$ \\
PRFT & $15.267^{* * *}(0.0259)$ & $4.1213(0.5559)$ & $19.616^{* * *}(0.0019)$ \\
RISK_T & $-0.2173^{* * *}(0.0047)$ & $0.1824^{* * *}(0.0247)$ & $-0.1642^{* * *}(0.0106)$ \\
C & 0.8786 & -0.8740 & 0.1183 \\
\hline
\end{tabular}




\begin{tabular}{llll}
\hline R-squared & 0.8304 & 0.7050 & 0.9537 \\
Adjusted R-squared & 0.7406 & 0.5488 & 0.9291 \\
F-statistic & 9.2473 & 4.5133 & 38.8828 \\
Prob(F-statistic) & 0.0000 & 0.0037 & 0.0000 \\
\hline
\end{tabular}

SSBSIZE, total members of Shariah supervisory board. BSIZE, number of Board of directors. B-IND, percentage of independent board members. B-MET, number of real annual meetings of the board. CEOD is used for the duality of CEO duty at a time. CG-FM, total percentage of females as the board of directors. F-SIZE is used for the size of the firm. PRFT is used for profitability. RISK_T is used for risk-taking.

The impact of governance and risk-taking has been examined through Technical efficiency, pure technical efficiency, and scale efficiency. Results of Islamic banks of Pakistan indicate that in the case of Technical efficiency, board independence has a positive and significant impact on its efficiency. Females as part of the board also have a positive and meaningful relationship with technical efficiency. Profitability also has a positive and significant association with technical efficiency.

At the same time, risk-taking has a significant negative impact on technical efficiency. Secondly, in the case of pure technical efficiency, Board independence, board meetings, females as part of the board, and risktaking have a positive and significant relationship with Pakistan's Islamic banks' pure technical efficiency. Thirdly, in the case of Scale efficiency, Shariah supervisory board, board meetings, and risk-taking have a negative but significant association with the efficiency of IBs of Pakistan. While, Board independence, females as part of the board, firm size, and profitability have a significant positive association with Pakistan's Islamic banks' scale efficiency.

Table 4 - Descriptive Statistics of Malaysian IBs

\begin{tabular}{|c|c|c|c|c|c|c|c|c|c|c|c|c|}
\hline & TE & PTE & SE & SSB-SIZE & BSIZE & B-IND & B-MET & CEOD & CG-FM & F-SIZE & PRFT & RISK_T \\
\hline Mean & 0.692 & 0.776 & 0.705 & 0.771 & 0.919 & 0.531 & 0.942 & 0.733 & 0.128 & 7.468 & 0.007 & 0.817 \\
\hline Median & 0.814 & 0.820 & 0.814 & 0.778 & 0.954 & 0.545 & 0.903 & 1.000 & 0.111 & 7.607 & 0.010 & 0.576 \\
\hline Maximum & 0.910 & .914 & 0.910 & 0.954 & 1.079 & 0.778 & 1.380 & 1.000 & 0.400 & 8.862 & 0.231 & 2.344 \\
\hline Minimum & 0.008 & 0.427 & 0.008 & 0.477 & 0.602 & 0.250 & 0.477 & 0.000 & 0.000 & 5.617 & -0.316 & 0.150 \\
\hline Std. Dev. & 0.262 & 0.117 & 0.241 & 0.105 & 0.119 & 0.118 & 0.205 & 0.447 & 0.097 & 0.960 & 0.060 & 0.481 \\
\hline Skewness & -1.908 & -0.808 & -2.103 & -0.655 & -1.418 & -0.262 & 0.351 & -1.055 & 0.377 & -0.759 & -2.419 & 0.972 \\
\hline Kurtosis & 5.491 & 2.953 & 6.645 & 3.807 & 4.482 & 2.671 & 2.630 & 2.114 & 2.871 & 2.679 & 24.201 & 3.442 \\
\hline
\end{tabular}

Above table 4 contains descriptive statistics of Malaysian Islamic banks. Descriptive statistics indicate that Malaysian Islamic banks have about $69 \%$ technical efficiency. The mean value of pure technical efficiency is $77 \%$, suggesting that Malaysian Islamic banks have $77 \%$ pure technical efficiency. The mean value of scale efficiency is $70 \%$, which means Malaysian Islamic banks have about $70 \%$ scale efficiency levels.

Table 5 - Correlation Matrix of Malaysian IBs

\begin{tabular}{|c|c|c|c|c|c|c|c|c|c|}
\hline Probability & SSB-SIZE & BSIZE & B-IND & B-MET & CEOD & CG-FM & F-SIZE & PRFT & RISK_T \\
\hline SSB_SIZE & 1.000 & & & & & & & & \\
\hline CG_B_SIZE & 0.002 & 1.000 & & & & & & & \\
\hline BORD_INDPND & $0.005^{* *}$ & 0.002 & 1.000 & & & & & & \\
\hline B_MEETNG & $0.012^{* *}$ & $0.009 * *$ & 0.006 & 1.000 & & & & & \\
\hline CEO_DAULITY & 0.002 & 0.002 & 0.009 & -0.002 & 0.196 & & & & \\
\hline CG_FEMALE & $0.005^{* *}$ & 0.001 & 0.002 & $0.014^{* *}$ & -0.002 & 1.000 & & & \\
\hline FRIM_SIZE & $0.014^{* *}$ & $-0.031 *$ & -0.005 & $0.048^{*}$ & -0.049 & $0.043^{* *}$ & 1.000 & & \\
\hline PROFITABLITY & -0.001 & 0.000 & 0.000 & 0.001 & -0.006 & 0.001 & -0.005 & 1.000 & \\
\hline RISK_TAKING & -0.007 & 0.000 & 0.002 & 0.011 & 0.043 & $0.016^{* *}$ & 0.104 & 0.006 & 1.000 \\
\hline
\end{tabular}

Table 5 contains a correlation analysis of all independent variables in the case of Malaysian Islamic banks. SSB size has a positive and statistically significant correlation with board independence, board meetings, females as part of the board, and firm size. The Board of director's size has a positive and significant correlation with discussions of the board. At the same time, it has a negative but significant correlation with firm size. Board meetings positively and significantly correlate with females as part of the firm's board and size. Females 
as part of the board have a positive and significant correlation with Malaysia's Islamic banks' firm size and risktaking. The rest of the variables have no positive or negative correlation with other variables.

Table 6 - Results of Malaysian IBs

\begin{tabular}{|c|c|c|c|}
\hline & TE & PTE & SE \\
\hline SSB-SIZE & $0.0834 * * *(0.0086)$ & $0.0814 *(0.0708)$ & $0.03785^{* * *}(0.0076)$ \\
\hline BSIZE & 0.1609 (0.1726) & $0.5891(0.1145)$ & $0.5006(0.1891)$ \\
\hline B-IND & $0.2186^{* * *}(0.0236)$ & $0.2386^{* * *}(0.0569)$ & $0.1955^{* * *}(0.0521)$ \\
\hline B-MET & $0.2937 * * *(0.0044)$ & $-0.5900 * *(0.0601)$ & $-0.3744(0.2379)$ \\
\hline CEOD & $-0.0004(0.9894)$ & $0.1723^{* * *}(0.0588)$ & $0.1546 *(0.0967)$ \\
\hline CG-FM & $0.2978(0.1913)$ & $1.1712(0.1051)$ & $0.7897(0.2822)$ \\
\hline F-SIZE & $0.0320 * *(0.0421)$ & $0.0803(0.1017)$ & $0.0482(0.3324)$ \\
\hline PRFT & $-0.0366(0.8686$ & $-0.2469(0.7237)$ & $-0.5204(0.4693)$ \\
\hline RISK_T & $-0.0834 * * *(0.0067)$ & $-0.2930 * * *(0.028)$ & $-0.1674 * *(0.0823)$ \\
\hline $\mathrm{C}$ & 0.1919 & -0.0969 & 0.2516 \\
\hline R-squared & 0.6777 & 0.3627 & 0.2063 \\
\hline Adjusted R-squared & 0.5949 & 0.1988 & 0.0022 \\
\hline F-statistic & 8.1783 & 2.2130 & 1.0107 \\
\hline Prob(F-statistic) & 0.0000 & 0.0450 & 0.4503 \\
\hline
\end{tabular}

SSBSIZE, total members of Shariah supervisory board. BSIZE, number of Board of directors. B-IND, percentage of independent board members. B-MET, number of total annual meetings of the board. CEOD is used for the duality of CEO duty at a time. CG-FM, total percentage of females as the board of directors. F-SIZE is used for the size of the firm. PRFT is used for profitability. RISK_T is used for risk-taking.

Above table 6 contains the regression results of Malaysian Islamic banks. Results show that in the case of technical efficiency, the Size of the Shariah supervisory board, Board independence, Board meetings, and firm size have a positive and significant impact on Malaysian Islamic banks' technical efficiency. On the other hand, risk-taking has a significant negative relationship with technical efficiency. Secondly, in pure technical efficiency, Shariah supervisory board size, board independence, and CEO duality have a positive and significant association with pure technical efficiency. Moreover, board meetings and risk-taking have a negative but significant impact on pure technical efficiency. Thirdly, in scale efficiency, Shariah supervisory board size, board independence, and CEO duality have a positive and meaningful relationship. On the contrary, risk-taking has a negative but significant impact on Malaysia's Islamic banks' scale efficiency.

\section{Conclusion and recommendations}

This study's main aim was to compare governance, risk-taking, and efficiency of pure Islamic banks of Pakistan and Malaysia by using nine years of data from 2009 to 2017. We use three proxies of efficiency (Technical efficiency, Pure technical efficiency, and scale efficiency). This comparative study shows that Shariah supervisory board has a significant impact only on Malaysian Islamic banks with technical, pure specialized, and scale efficiency. At the same time, board independence has a positive and significant relationship with both countries' Islamic banks' efficiency. Board meetings have a significant positive impact on Pakistani banks' pure technical efficiency while it substantially affects Malaysian banks' technical efficiency.

CEO duality has a significant impact on the efficiency of only Malaysian banks. Females as part of the board have a substantial effect on the efficiency of Pakistani banks. Bank size has a significant impact on Pakistani banks' scale efficiency while it significantly impacts the technical efficiency of Malaysian banks. Results also show that risk-taking has a significant negative impact on the efficiency of both countries. Finally, based on the compression between Malaysian and Pakistani IBs, we conclude that Pakistani Islamic banks should focus more on Shariah supervisory boards for developing the Islamic banking system in Pakistan because the Shariah supervisory board has a significant impact on the Efficiency of Malaysian IBs. Based on our comparative results, we recommend that management of Pakistani Islamic Banks focus more on Shariah board and CEO duality so that Pakistani Islamic banks may become more efficient like Malaysian Banks. 


\section{Limitation and Future Direction}

Firstly, this research study has limited data because we used just nine years of data from 2009 to 2017, so the data's future duration should be expanded. Secondly, we used limited shariah governance variables; in the future, other essential elements should be studied like Qualifications of Shariah board members, Shariah Board members' Experience, Shariah supervisory board meetings, etc. see more results.

Funding: This research received no external funding.

Acknowledgments: We acknowledge there was no external funding support; all authors contributed accordingly in every part of the paper.

Conflicts of Interest: The authors declare no conflict of interest.

\section{References}

Abbas, Q., Yussof, S. A., \& Anjum, M. N. (2020). A Quantitative Study of the Role Shariah Boards and Bank Ownership Structures Play in Enhancing the Financial Performance of Islamic Banks: A Case of Pakistan. ICR Journal, 11(2), 204-224.

Abdul Rahman, A. R., \& Rosman, R. (2013). Efficiency of Islamic Banks: A Comparative Analysis of MENA and Asian Countries. Journal of Economic Cooperation \& Development, 34(1).

Adams, R. B., \& Mehran, H. (2012). Bank board structure and performance: Evidence for large bank holding companies. Journal of financial Intermediation, 21(2), 243-267.

Ahmad, N. H. B., Noor, M. A. N. M., \& Sufian, F. (2010). Measuring Islamic banks efficiency: the case of world Islamic banking sectors.

Alabdullah, T. T. Y., Yahya, S., \& Ramayah, T. (2014). Corporate governance mechanisms and Jordanian companies' financial performance. Asian Social Science, 10(22), 247.

Aly, H. Y., Grabowski, R., Pasurka, C., \& Rangan, N. (1990). Technical, scale, and allocative efficiencies in US banking: An empirical investigation. The review of economics and statistics, 211-218.

Bader, M. K. I., Mohamad, S., Ariff, M., \& Shah, T. H. (2008). Cost, revenue, and profit efficiency of Islamic versus conventional banks: international evidence using data envelopment analysis. Islamic economic studies, 15(2).

Bahrini, R. (2017). Efficiency analysis of Islamic banks in the Middle East and North Africa region: A bootstrap DEA approach. International Journal of Financial Studies, 5(1), 7.

Banker, R. D., Charnes, A., \& Cooper, W. W. (1984). Some models for estimating technical and scale inefficiencies in data envelopment analysis. Management science, 30(9), 1078-1092.

Basyith, A. (2016). Corporate governance, intellectual capital, and firm performance. Research in Applied Economics, 8 (1), 17-41.

Bhagat, S., \& Black, B. (2001). The non-correlation between board independence and long-term firm performance. J. CorP. l., 27, 231.

Bhagat, S., \& Bolton, B. (2008). Corporate governance and firm performance. Journal of corporate Finance, 14(3), 257-273.

Brown, L. D., \& Caylor, M. L. (2006). Corporate governance and firm valuation. Journal of accounting and public policy, 25(4), 409-434.

Chames, A., Cooper, W. W., \& Rhodes, E. (1978). Measuring the efficiency of decision making units. European journal of operational research, 2(6), 429-444.

De Andres, P., \& Vallelado, E. (2008). Corporate governance in banking: The role of the board of directors. Journal of Banking \& Finance, 32(12), 2570-2580.

Drakos, A., \& Bekiris, F. (2010). Corporate performance, managerial ownership and endogeneity: A simultaneous equations analysis for the Athens stock exchange. Research in International Business and Finance, 24(1), 24-38. 
Fu, X. M., Lin, Y. R., \& Molyneux, P. (2014). Bank competition and financial stability in Asia Pacific. Journal of Banking \& Finance, 38, 64-77.

Gishkori, M. A., \& Ullah, N. (2013). Technical efficiency of Islamic and commercial banks: evidence from Pakistan using DEA model (2007-2011). Journal of Business and Management, 7(4), 68-76.

Haron, S., Abu Bakar, N. M., \& Tahir, I. M. (2011). Evaluating efficiency of Islamic banks using Data Envelopment Analysis: international evidence. Journal of Islamic Economics, Banking and Finance, 113(464), $1-14$.

Hassan, M. K., \& Hussein, K. A. (2003). Static and dynamic efficiency in the Sudanese banking system. Review of Islamic Economics, 14(1), 5-48.

Hassine, M. B., \& Limani, R. (2014). The impact of bank characteristics on the efficiency: Evidence from MENA Islamic banks. Journal of Applied Finance and Banking, 4(3), 237.

Jensen, M. C., \& Meckling, W. H. (1976). Theory of the firm: Managerial behavior, agency costs and ownership structure. Journal of financial economics, 3(4), 305-360.

Johnes, J., Izzeldin, M., \& Pappas, V. (2009). The efficiency of Islamic and conventional banks in the Gulf Cooperation Council (GCC) countries: An analysis using financial ratios and data envelopment analysis.

Johnes, J., Izzeldin, M., \& Pappas, V. (2014). A comparison of performance of Islamic and conventional banks 2004-2009. Journal of Economic Behavior \& Organization, 103, S93-S107.

Kamarudin, F., Sufian, F., Loong, F. W., \& Anwar, N. A. M. (2017). Assessing the domestic and foreign Islamic banks efficiency: Insights from selected Southeast Asian countries. Future Business Journal, 3(1), 33-46.

Khan, M. I., \& Shah, I. A. (2015). Cost efficiency and total factor productivity of Islamic and conventional banks in Pakistan. Research Journal of Finance and Accounting, 6(5), 135-146.

Klapper, L. F., \& Love, I. (2004). Corporate governance, investor protection, and performance in emerging markets. Journal of corporate Finance, 10(5), 703-728.

Mezzi, N. (2018). Efficiency of Islamic banks and role of governance: empirical evidence. Managerial Finance.

Mitton, T. (2002). A cross-firm analysis of the impact of corporate governance on the East Asian financial crisis. Journal of financial economics, 64(2), 215-241.

Mohd Abbas, S. Z., Abdul Rahman, R., \& Mahenthrian, S. (2009). Ultimate ownership and performance of Islamic Financial Institutions in Malaysia. Paper presented at the Asian Finance Association Conference, July.

Mollah, S., \& Zaman, M. (2015). Shari'ah supervision, corporate governance and performance: Conventional vs. Islamic banks. Journal of Banking \& Finance, 58, 418-435.

Musa, H. (2020). Corporate Governance and Financial Performance of Nigeria Listed Banks. Jour of Adv Research in Dynamical \& Control Systems, 12(1).

Olson, D., \& Zoubi, T. A. (2011). Efficiency and bank profitability in MENA countries. Emerging markets review, 12(2), 94-110.

Pasiouras, F. (2008). International evidence on the impact of regulations and supervision on banks' technical efficiency: an application of two-stage data envelopment analysis. Review of Quantitative Finance and Accounting, 30(2), 187-223.

Rashid, A., De Zoysa, A., Lodh, S., \& Rudkin, K. (2010). Board composition and firm performance: Evidence from Bangladesh. Australasian Accounting, Business and Finance Journal, 4(1), 76-95.

Rosman, R., Abd Wahab, N., \& Zainol, Z. (2014). Efficiency of Islamic banks during the financial crisis: An analysis of Middle Eastern and Asian countries. Pacific-Basin Finance Journal, 28, 76-90.

Saeed, M. B., \& Saeed, S. K. (2018). Characteristics of Shariah supervisory board, corporate governance mechanisms and efficiency of Islamic banks: evidence from listed banks in Asia. Journal of Islamic Business and Management, 8(1), 116-138.

Said, A. (2012). Efficiency in Islamic banking during a financial crisis-an empirical analysis of forty-seven banks. Journal of Applied Finance \& Banking, 2(3), 163-197.

Said, A. (2013). Evaluating the overall technical efficiency of Islamic banks operating in the MENA region during the financial crisis. International Journal of Economics and Financial Issues, 3(2), 426-434. 
Spong, K., Sullivan, R. J., \& DeYoung, R. (1995). What makes a bank efficient? A look at financial characteristics and bank management and ownership structure. Federal Reserve Bank of Kansas City, Financial Industry Perspectives, December, 1-19.

Srairi, S., Kouki, I., \& Harrathi, N. (2012). Efficiency and stock market performance of Islamic banks in GCC Countries. ISRA International Journal of Islamic Finance, 4(2), 89-116.

Sufian, F. (2007). The efficiency of Islamic banking industry: A non-parametric analysis with non-discretionary input variable. Islamic economic studies, 14(1).

Sufian, F., \& Noor, M. A. N. M. (2009). The determinants of Islamic banks' efficiency changes. International Journal of Islamic and Middle Eastern Finance and Management.

Yudistira, D. (2004). Efficiency in Islamic banking: an empirical analysis of eighteen banks. Islamic economic studies, 12(1).

Yusoff, W. F. W., \& Alhaji, I. A. (2012). Corporate governance and firm performance of listed companies in Malaysia. Trends and Development in Management Studies, 1(1), 43-65.

Zouari, S. B. S., \& Taktak, N. B. (2014). Ownership structure and financial performance in Islamic banks. International Journal of Islamic and Middle Eastern Finance and Management. 